Article

\title{
Spatial and Temporal Variability of the Floral Scent Emitted by Barlia robertiana (Loisel.) Greuter, a Mediterranean Food-Deceptive Orchid
}

\author{
Vito Antonio Romano ${ }^{1}$, Leonardo Rosati ${ }^{2, *(\mathbb{D})}$, Simonetta Fascetti ${ }^{2}$ (D), Anna Maria Roberta Cittadini ${ }^{1}$, \\ Rocco Racioppi ${ }^{1}$, Richard Lorenz ${ }^{3}$ and Maurizio D'Auria ${ }^{1, *(D)}$
}

1 Dipartimento di Scienze, Università della Basilicata, V.le dell'Ateneo Lucano 10, 85100 Potenza, Italy; vitoantonio_romano@libero.it (V.A.R.); anna.cittadini@hotmail.it (A.M.R.C.); rocco.racioppi@unibas.it (R.R.)

2 Scuola di Scienze Agrarie, Forestali, Alimentari e Ambientali, Università della Basilicata, Via Ateneo Lucano 10, 85100 Potenza, Italy; simonetta.fascetti@unibas.it

3 Arbeitskreis Heimische Orchideen Baden-Württemberg, D-69469 Weinheim, Germany; lorenz@orchids.de

* Correspondence: leonardo.rosati@unibas.it (L.R.); maurizio.dauria@unibas.it (M.D.); Tel.: +39-0971-205-480 (M.D.)

check for

updates

Citation: Romano, V.A.; Rosati, L.;

Fascetti, S.; Cittadini, A.M.R.;

Racioppi, R.; Lorenz, R.; D'Auria, M. Spatial and Temporal Variability of the Floral Scent Emitted by Barlia robertiana (Loisel.) Greuter, a

Mediterranean Food-Deceptive

Orchid. Compounds 2022, 2, 37-53.

https://doi.org/10.3390/

compounds2010004

Academic Editor: Juan Mejuto

Received: 13 November 2021

Accepted: 4 January 2022

Published: 27 January 2022

Publisher's Note: MDPI stays neutral with regard to jurisdictional claims in published maps and institutional affiliations.

Copyright: (C) 2022 by the authors. Licensee MDPI, Basel, Switzerland. This article is an open access article distributed under the terms and conditions of the Creative Commons Attribution (CC BY) license (https:// creativecommons.org/licenses/by/ $4.0 /)$.
Abstract: This study on Barlia robertiana aims to: (1) assess whether scent is variable between populations; (2) evaluate whether scent composition may be related to geographical variables; (3) assess whether there are VOC differences during the flowering phase; and (4) assess whether there are yearly VOC variabilities. SPME sampling was used. Fourteen plants, collected along an ecological gradient, were analyzed. A multivariate analysis was performed through ordination and hierarchical cluster analysis. Compositions versus geographic distances were also analyzed using Mantel test. Seventy compounds were identified. Multivariate analyses and Mantel tests detected no correlations between VOC composition and both geographic and ecological variables. These results may suggest that there is no adaptation of floral scent to local environments. VOC compositions during the flowering phase showed a slight change but a strong variability between individuals. A huge difference was found in the pairwise comparison of the plants analyzed in different years. The high scent variability can be interpreted as a strategy of a non-rewarding but allogamous species to not allow the learning by pollinators. In fact, disrupting the association among floral scent signals with the lack of nectar may enhance the fruit set via a higher probability of being visited by insects.

Keywords: Basilicata; Barlia robertiana; Himantoglossum robertianum; mantel test; Orchidaceae; pollination syndrome; Italy; volatile compounds

\section{Introduction}

Orchidaceae are one of the largest families of vascular plants [1]; since Darwin [2], they have attracted the interests of a plethora of naturalists for the amazing floral variations and the complex pollination mechanisms which they evolved [3]. Approximately one-third of Orchidaceae are believed to deceive insect pollinators [4,5]; among the mechanisms of deception, generalized food deception is one of the most common mechanisms developed by orchids for efficient pollen exportation $[5,6]$. These species can exploit the existing plant-pollinator relationships and achieve pollination through deception in the absence of floral rewards for pollinators. The similarity with rewarding plants determines their reproductive success; therefore, this pollination syndrome can be considered a generalized form of Batesian mimicry [7]. In order to deceive pollinators, these orchids exploit general floral signals typical for rewarding plant species, including flower color and scent [8]. However, they generally do not resemble any specific rewarding flower and they are visited by casual pollinators or exploratory pollinators [9]. For an example of floral mimicry, see [10] and references therein. It has been shown that orchids related to generalized food 
deception exploit bees and bumblebees that have just emerged after the winter season, blooming in early spring [11]. Moreover, reward-less species undoubtedly benefit from the simultaneous flowering of nectariferous species present in the same habitat that increase the possibility of being visited by local pollinators [12].

Floral scent, together with size, shape and color, act as signals attracting pollinators [13], and adaptations to specific pollinators are considered an important driver of evolution in angiosperms.

Barlia robertiana (Loisel.) Greuter (Orchidaceae) has non-rewarding flowers, and it is obligatorily insect-pollinated. It is a Mediterranean species [14] typical of several habitats such as clearings in scrublands and thermophilus woods, dry grasslands, roads edge, usually on bases-rich soils [15]. Recent extensions north due to climate change have been observed in western Switzerland [16] and southwestern Germany [17]. Its geographical distribution in Italy encompasses all the regions, but is lacking in some of the Alpine sectors [18]. It is particularly widespread in the Basilicata region (Southern Italy), from the coast to the mountains of the Apennines up to approximately $1000 \mathrm{~m}$ a.s.l. (above see level).

According to a recent molecular genetic study [19], the genus Barlia should be transferred to the genus Himantoglossum; however, a general consensus about this taxonomical rearrangement has not been reached by taxonomists; in this article, we refer to the nomenclature of the most recent checklist of the Italian vascular flora [18].

The plants are robust (up to 80-110 cm high) and early flowering, from December to April. The inflorescence is sub-cylindrical, dense and multi-flowered; it is up to $40 \mathrm{~cm}$ high and can develop up to 70 flowers; the color of flowers varies from red-violet to olive-green or brown-red; inside, it is covered with purplish spots [14]. The lip borders are crenate, with a papillose epidermis; the spur is conical, shorter than the ovary, turned downwards, and it does not produce nectar. The flowers give off a delicate, persistent, and easily perceptible smell. Structural particularities of epigeous and hypogeous plant organs of B. robertiana, in comparison with $H$. hircinum, have been interpreted as morphological adaptations to different edaphic and environmental conditions [20]. Hydroalcoholic flower extracts of B. robertiana revealed the presence of phenols, flavonoids, and proanthocyanidins [21]. Chromosomes $(2 n=32)$, karyotypes, and the localization of ribosomal genes have been studied [22]. Unlike other Mediterranean orchids, such as the genus Ophrys, which are pollinated by specialized bees [3], several different groups of insects have been identified to pollinate B. robertiana, such as Apoidea (Hymenoptera) and Cetoniidae (Coleoptera) [23,24]. A recent study on the fruit set of B. robertiana, performed on the island of Mallorca (Spain), confirmed the importance of allogamy for its reproduction success [25].

Although the scent of orchids has frequently been analyzed in evolutionary studies or to identify potential chemical fragrances, knowledge about most of the species are still incomplete; moreover, studies of floral scent variations at population level including more than just a few individuals are particularly scarce. In particular, knowledge about the spatial and temporal variability of the floral scents emitted by flowers is almost completely absent.

In this study, we aim to describe the spatial and temporal variability of the spectrum of volatile compounds emitted by flowers of B. robertiana, testing the ability of this species to adapt to different environmental conditions to be attractive to different potential pollinators.

B. robertiana, with respect to other groups of orchids, is not plagued by taxonomic problems at species level that could determine some confounding effects due to identification discrepancies by the botanists. Moreover, it has large populations in southern Italy, and it has a broad range, spreading along a large climatic gradient, at regional level. Thus, it represents an ideal case study to explore the temporal, ecological, and spatial variability in emitted floral volatile compounds (VOCs). In particular, in this study, we aim to: (1) assess whether the chemical composition is variable between plants collected at different sites; (2) evaluate whether chemical composition of the scent is related to geographical or environmental variables; (3) assess whether there are temporal differences in VOC compositions during the flowering phase, comparing floral volatile compounds emitted at the beginning 
and at the end of the flowering; and (4) assess whether there is a between-year variability in VOC compositions emitted by the same plant.

\section{Experimental Section}

To assess spatial variability, fourteen B. robertiana plants were collected from different populations in the Basilicata region (Southern Italy) from the coast to the inner mountain area (Figure 1) within altitude ranges from $10 \mathrm{~m}$ a.s.l. to $727 \mathrm{~m}$ a.s.l. Plants were collected in 2017 and cultivated into pots at the campus of the University of Basilicata (Potenza, Italy). In the following year (2018), inflorescences with fully opened flowers were incapsulated in a of 6.5 glass bell (Figure 2). Sampling was performed under light conditions, in an air-conditioned room $\left(21 \pm 1^{\circ} \mathrm{C}\right)$ to guarantee a stable temperature. VOC sampling followed the protocol we used in a recent study on the floral volatiles of the genus Gymnospermium [26].
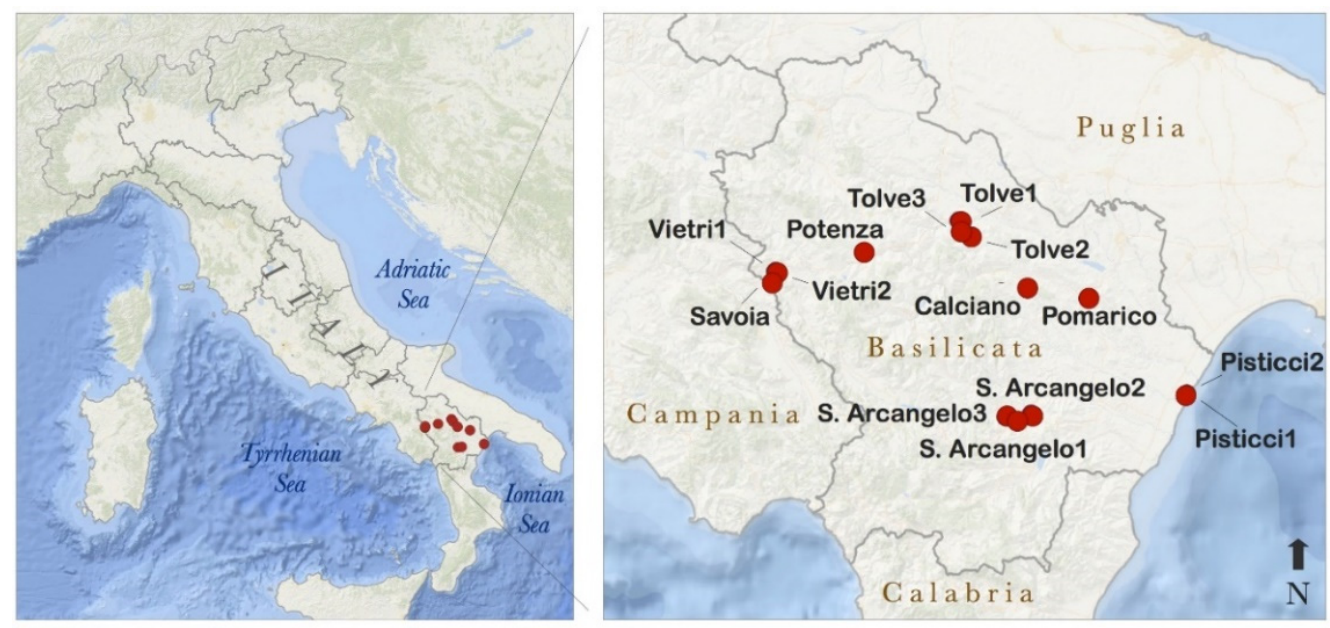

Figure 1. Study area and sampling point locations in the Basilicata region (southern Italy). Labels of the samples correspond with the municipality names where plants were collected.

Analysis of VOCs was performed using HS-SPME with a DVB/CARB/PDMS fiber. A preliminary set of analysis was conducted to optimize the sampling time: these analyses were performed at three different adsorption times of the fiber (5-24-72 h). The highest number of identified compounds (20) was detected when the SPME fiber was exposed for $24 \mathrm{~h}$ (Appendix A, Table A1); therefore, we used this interval of fiber exposition in this study. The fiber was exposed to the headspace and then withdrawn into the needle and transferred to a GC/MS system. A 50/30 $\mu \mathrm{m}$ DVB/CAR/PDMS module (57328-U, Supelco, Milan, Italy) was employed to determine VOCs. Analyses were accomplished with an HP 6890 Plus gas chromatograph (Agilent) equipped with a Phenomenex Zebron ZB-5 MS capillary column $(30 \mathrm{~m} \times 0.25 \mathrm{~mm}$ i.d. (inner diameter) $\times 0.25 \mu \mathrm{m}$ FT) (Agilent, Milan, Italy). An HP 5973 mass selective detector (Agilent) was utilized with helium at $0.8 \mathrm{~mL} / \mathrm{min}$ as the carrier gas. A splitless injector was maintained at $250{ }^{\circ} \mathrm{C}$ and the detector at $230{ }^{\circ} \mathrm{C}$. The oven was maintained at $40^{\circ} \mathrm{C}$ for $2 \mathrm{~min}$, then gradually warmed, $8{ }^{\circ} \mathrm{C} / \mathrm{min}$, up to $250^{\circ} \mathrm{C}$ and held for $10 \mathrm{~min}$ (Figure 3). Tentatively identification of aroma components was based on mass spectra and NIST 11 library comparison. A single VOC peak was considered as identified when its experimental spectrum matched with a score over $90 \%$ with ones present in the library and if the retention time was in agreement with the reported retention index. Retention indices were calculated using standard $n$-alkane solution (49452-U, C7-C40 saturated alkanes standard, Sigma-Aldrich, Milan, Italy). 


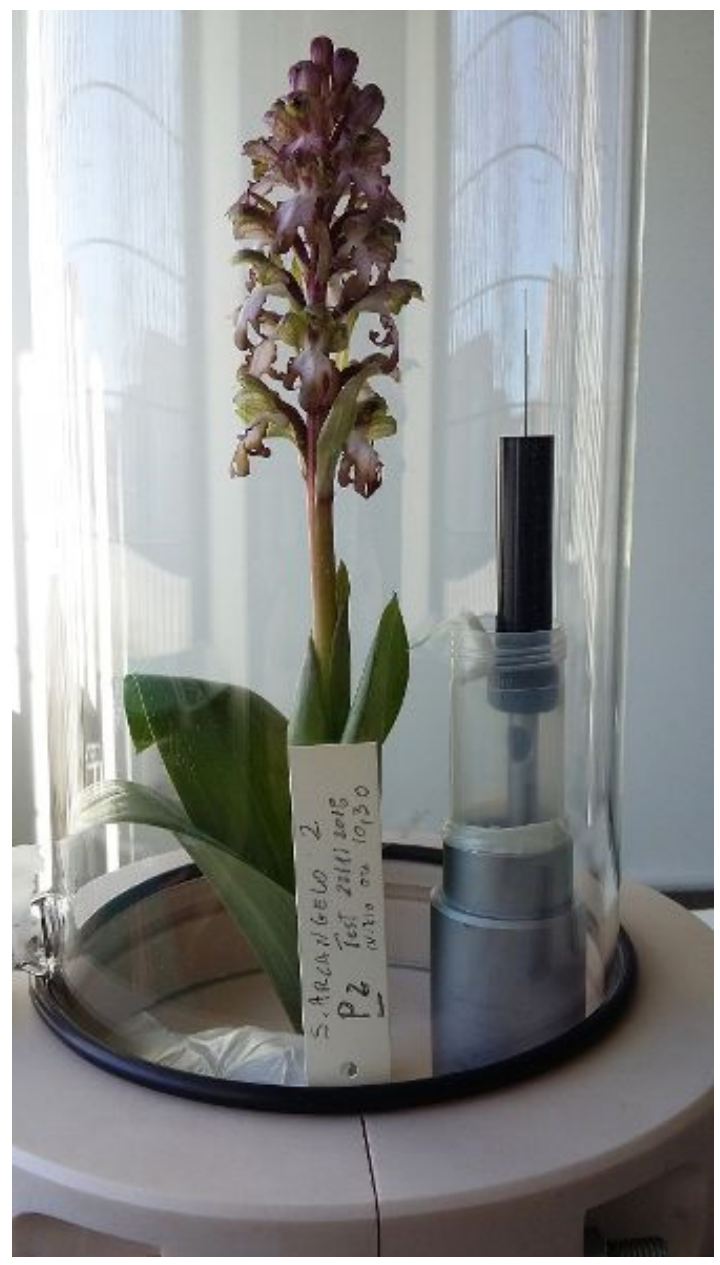

Figure 2. A Barlia robertiana plant from the site of S. Arcangelo (Basilicata, Italy) in the experimental conditions for floral VOC sampling using a 50/30 $\mu \mathrm{m}$ DVB/CAR/PDMS fiber (photograph: V.A. Romano).

A multivariate analysis of VOC compositions was performed through non-metric multidimensional scaling (NMDS) as an ordination technique and hierarchical cluster analysis (HCA). Bray-Curtis dissimilarity was used for both NMDS and HCA using the relative abundance of each compounds as sample variable. For HCA, we used the unweighted pair group method with arithmetic mean (UPGMA) technique as an agglomerative method. Variables with Spearman's rho correlation coefficient $>0.65$ with ordination axes were superimposed in the scatter diagram.

Concerning spatial analyses, we tested whether geographic distance and environmental variables influence the VOC compositions of samples. Site-specific soil data were not available; therefore, we approximated differences in the environmental niche using slope, aspect, altitude, and bioclimatic data. For each sample point, the most relevant phytoclimatic indices $[27,28]$ were extracted from the high-resolution raster dataset developed to realize the bioclimate map of Italy [29]. These indices were: yearly positive temperatures $(\mathrm{Tp}=$ sum of the monthly mean temperatures of months with average temperatures $\left.>0{ }^{\circ} \mathrm{C}\right)$; annual positive precipitation $(\mathrm{Pp}=$ total average precipitation of months with average temperature $\left.>0{ }^{\circ} \mathrm{C}\right)$; thermicity index $(\mathrm{T}+\mathrm{m}+\mathrm{M})$; annual ombrothermic index $=(\mathrm{Pp} / \mathrm{Tp})$; continentality index $\left(\mathrm{T}_{\max }-\mathrm{T}_{\min }\right)$; ombrothermic index of the warmest summer bimester $\left(\operatorname{Ios}_{2}=\left(\mathrm{Pp}_{2} / \mathrm{Tp}_{2}\right)\right.$. According to the approach we used for population genetics of Centaurea filiformis [30], the correlations between VOC compositions and both geographic and environmental distances were assessed using Mantel tests implemented in the software PAST. Geographic distances were log-transformed and 
environmental distances were obtained by means of analyzing the Euclidean distance after data standardization.

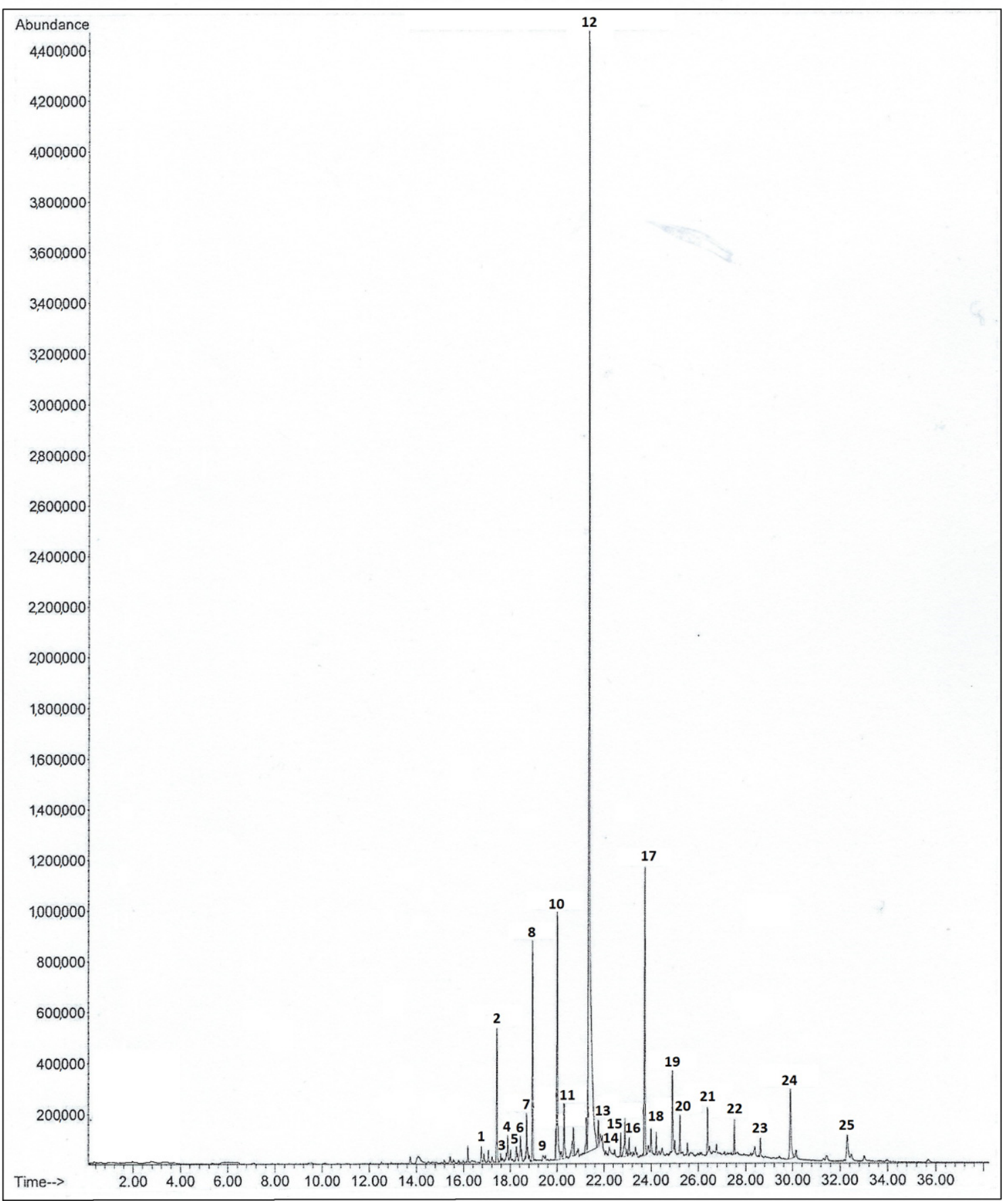

Figure 3. Gas chromatographic results of an SPME analysis of the VOCs of Barlia robertiana. 1: tetradecane; 2: caryophyllene; 3: sesquiphellandrene; 4: $\beta$-himalachene; 5: 1-(1,5-dimethyl-4hexenyl)-4-methylbenzene; 6: pentadecane; 7: $\beta$-bisabolene; 8: $\beta$-sesquiphellandrene; 9: hexadecane; 10: phthalate; 11: trans-farnesol; 12: 2,3-Dihydrofarnesol; 13: 2,6-diidopropylnaphthalene; 14: tetradecanoic acid; 15: octadecane; 16: pentadecanal; 17: phthalate; 18: nonadecane; 19: phthalate; 20: eicosane; 21: heneicosane; 22: docosane; 23: phthalate; 24: phthalate; 25: phthalate.

To assess temporal variability of flower scent in B. robertiana, two individuals collected from the S. Arcangelo population were sampled twice during 2019, following the same protocol described above. The first sampling was performed in the first part of the flowering 
phase, approximately when $50 \%$ of the flowers were open; the second sampling at the end of the flowering, when all the flowers were open. In addition, three individuals from Potenza, Calciano and S. Arcangelo were sampled in two consecutive years (2018 and 2019), in the same experimental conditions described above, to assess the between-year stability of floral emissions. Similarity between samples has been measured through the Bray-Curtis index.

\section{Results}

\subsection{Spatial Variability}

The 14 plants analyzed to assess the spatial variability of floral scent showed the presence of 70 compounds with a high variability between samples (min 14; max 28; mean 19.4). Remarkably, no compound was found to be present in all the samples. This variability has been observed considering both the composition and abundance of VOCs. Ethyl dodecanoate was the most frequent compound; it was determined in 11 samples. Hexadecane and $\beta$-bisabolene (Figure 4a) were detected in 10 samples, $\delta$-selinene and $\beta$-sesquiphellandrene (Figure 4e) were detected in 9 samples, whereas caryophyllene (Figure $4 \mathrm{~b}$ ), cis- $\alpha$-bergamotene (Figure $4 \mathrm{f}$ ), and heptadecane were found in 8 samples. Considering the most abundant compounds, each sample afforded a different result. Verbenone was the main component in Pisticci 1 and $\beta$-sesquiphellandrene in Pisticci 2; Calciano gave pristane as prevalent; in Sant'Arcangelo, the main components were alternatively $\alpha$-zingiberene, verbenone, and pristane. Caryophyllene was the principal component in Tolve 1, i-propyl 14-methyl-pentadecanoate was the main component in Tolve 2, whereas farnesol has the same role in Tolve 3. The Pomarico sample gave $p$-menth-8-en-1-ol as a main component (Figure 4c); in the two samples of Vietri, we found $\beta$-sesquiphellandrene and citronellol (Figure 4d) as dominant, whereas the Potenza plant gave pristane as the most abundant compound. $\beta$-Sesquiphellandrene was also the main component in the sample of Savoia. Only two compounds were found as dominant in more than two samples: pristane in S. Arcangelo 3, Calciano and Potenza and $\beta$-sesquiphellandrene in Pisticci 2, Vietri 1 and Savoia. Notably, except for Vietri 1 and Savoia, these groups comprise samples located rather distantly geographically. Coherently, the overall similarities between samples were rather low, with a mean value of $18.97 \pm 1.6 \mathrm{SE}$ ( $\min 0.96$, $\max 60.94)$. The full VOC compositions for each sample are reported in Table 1.

The NMDS ordination resulted in a two-dimensional solution with a final stress of 0.14 (Figure 5a). The VOCs most strongly correlated with the first axis were $\beta$-sesquiphellandrene (positively) and longipinene (negatively), whereas $p$-menth-8-en-1-ol (positively) and $i$-propyl 14-methyl-pentadecanoate (negatively) were the most correlated compounds with the second axis.

We did not identify a clear geographical structure in the dataset, except for the samples from Savoia and Vietri, which seemed to group together; these are also very close to each other geographically (Figure 1), and there was a weak correlation between axis 1 and altitude. However, in the NMDS, most of the samples coming from nearby locations (e.g., Tolve 1 vs. Tolve 3 and Pisticci 1 vs. Pisticci 2) were strongly separated along the two axes, and the position of the Potenza sample, located at the higher altitude, is not coherent.

Furthermore, in the hierarchical clustering (Figure 5b) within the subcluster including samples from Vietri and Savoia a sample from Pisticci was also unexpectedly included, the locality placed at the maximum geographical distance from Vietri and Savoia (Figure 1). The lack of a significative geographical driver underlying our dataset was also confirmed by the results of the Mantel test, which showed that there is no correlation between composition in VOCs and geographical distances between samples (Mantel test: $\mathrm{r}=0.17 ; p=0.19$ ).

The same result was obtained from analyzing the correlation between VOC composition and the environmental distances (i.e., ecological niche) of sample sites (Mantel test: $\mathrm{r}=0.10 ; p=0.28$. 


\subsection{Temporal Variability}

As for temporal differences in VOCs composition during the flowering phase, the comparison between floral volatiles emitted at the beginning and at the end of the flowering exhibited the presence of a similar number of compounds (min 15; max 22; mean 18.3). The mean value is in agreement with findings from the sampling performed to assess the spatial variability, where a mean value of 19.4 compounds was found. The VOC compositions for each sample are reported in Table 2. In particular, comparing the two flowering phases, we found the same number of compounds in sample 2 and a slight decrease in sample 1 at the end of the flowering. Additionally, in this case, despite the fact they come from the same population (S. Arcangelo), composition quantitative analysis confirmed the presence of a strong association between individuals' variability. In sample 1, the two most abundant compounds were caryophyllene and 2,3-dihydrofarnesol, whereas in sample 2, they were citronellol and $\beta$-sesquiphellandrene. Caryophyllene remained the dominant compound in the sample 1 even at the end of flowering, whereas the abundance of 2,3-dihydrofarnesol strongly decreased; then, the second most abundant compound became 4-methyltetradecane. In sample 2 , instead, the dominance between the first two compounds was reversed at the end of the flowering, with $\beta$-sesquiphellandrene becoming the most abundant compound followed by citronellol. The decrease in the number of compounds in sample 1 (from 22 to 15 ) is linked to the non-detection at the end of flowering of various compounds which, previously, had low abundance $($ area $\%<2)$, whereas only nonadecane, with an area value of $0.37 \%$, was found in addition at the end of flowering. On the other hand, in sample 2, five compounds were no longer identified at the end of flowering, replaced by an equal number of compounds not present in the first flowering phase. Among these, $\alpha$-terpineol acetate stands out for its abundance, characterized with a value of $13.83 \%$ in sample 2 at the end of flowering.
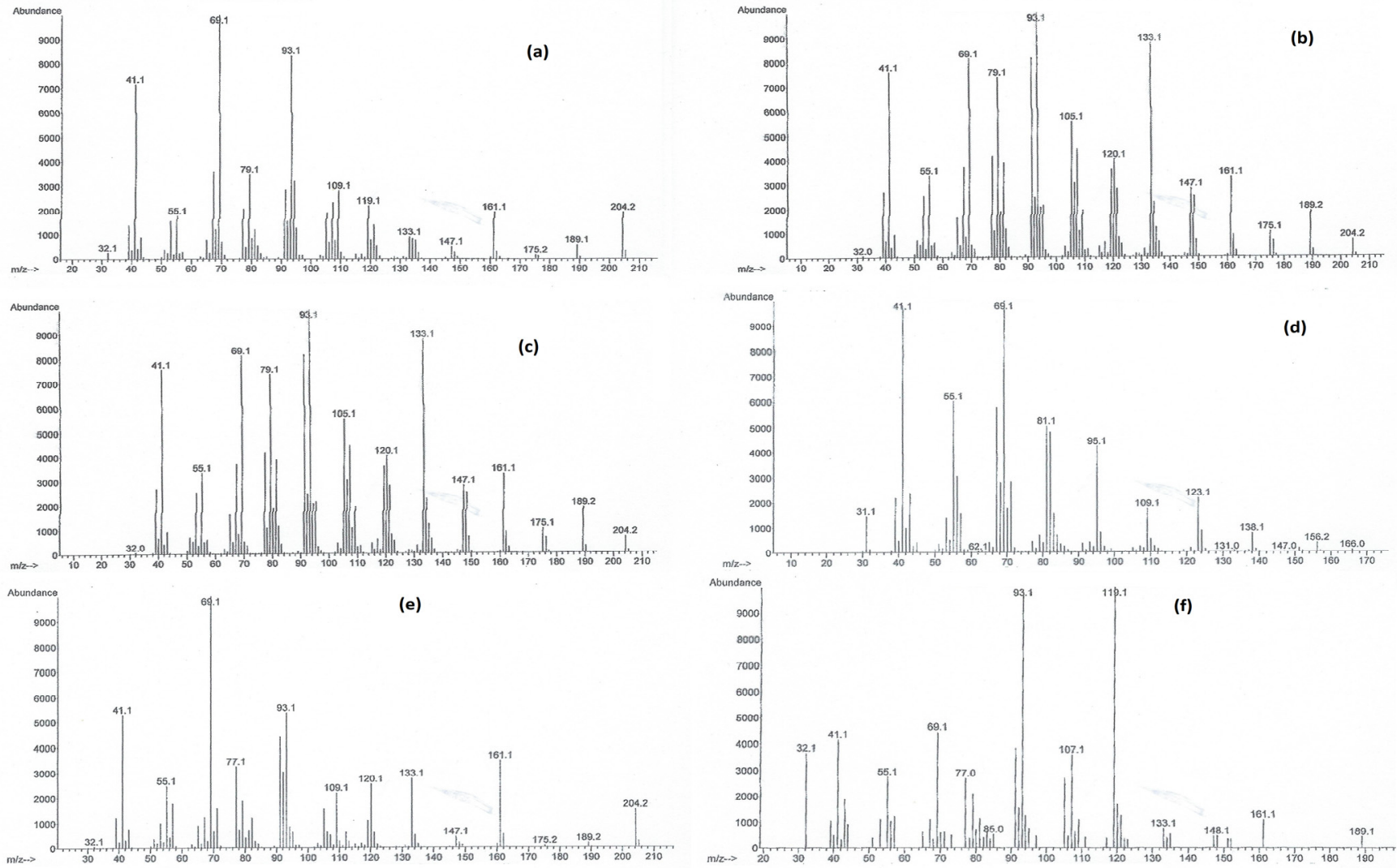

Figure 4. Mass spectra of (a) $\beta$-bisabolene; (b) caryophyllene (c) $p$-menth-8-en-1-ol; (d) citronellol; (e) $\beta$-sesquiphellandrene; (f) cis- $\alpha$-bergamottene. 
Table 1. VOCs detected from plant samples of Barlia robertiana sampled in the Basilicata region (S-Italy). Compounds are ordered by frequency in the table.

\begin{tabular}{|c|c|c|c|c|c|c|c|c|c|c|c|c|c|c|c|}
\hline Sample & & Pisticci 1 & Pisticci 2 & Calciano & S. Arcangelo 1 & S. Arcangelo 2 & S. Arcangelo 3 & Tolve 1 & Tolve 2 & Tolve 3 & Pomarico & Vietri 1 & Vietri 2 & Potenza & Savoia \\
\hline Compound & $\begin{array}{c}\text { r.t. } \\
\text { [min] }\end{array}$ & \multicolumn{14}{|c|}{ Area $[\%] \pm \mathbf{0 . 0 3}$} \\
\hline Ethyl dodecanoate & 19.93 & 0.33 & & 0.67 & 1.75 & 0.33 & 0.82 & 1.17 & 8.29 & & & 3.76 & 2.63 & 1.10 & 2.60 \\
\hline$\beta$-Bisabolene & 18.43 & 2.13 & & & & & 0.96 & 4.06 & 1.05 & 2.13 & 4.61 & 8.98 & 3.17 & 2.00 & 5.32 \\
\hline$\delta$-Selinene & 18.65 & 0.98 & & 7.04 & 9.06 & 17.59 & 6.49 & & 1.65 & & & 2.49 & 1.16 & 1.01 & 1.54 \\
\hline$\beta$-Sesquiphellandrene & 19.35 & & 29.06 & 0.91 & & & & & 2.94 & 8.39 & 17.59 & 43.08 & 15.14 & 8.97 & 25.05 \\
\hline Caryophyllene & 17.46 & & 8.51 & & & & & 24.63 & 10.11 & & 3.68 & 3.07 & 5.21 & 6.75 & 17.96 \\
\hline cis- $\alpha$-Bergamotene & 17.58 & 0.42 & 0.53 & 1.73 & & 0.77 & & & & & 0.77 & 14.04 & 4.15 & & 1.14 \\
\hline Heptadecane & 21.29 & & 0.74 & 7.41 & 1.43 & & & 0.73 & 2.94 & & & 2.24 & 1.49 & & 2.11 \\
\hline$\alpha$-Pinene & 7.79 & 0.49 & & 3.02 & & 0.46 & & 0.48 & 0.55 & & 0.92 & & & 7.87 & \\
\hline Citronellol & 14.36 & 0.57 & & & & 1.34 & & 2.53 & & 0.5 & & 1.77 & 17.96 & 1.53 & \\
\hline Methyl citronellate & 15.03 & & & 0.30 & & & & 0.75 & & 0.9 & 0.31 & 3.01 & 3.61 & & 1.85 \\
\hline Octadecane & 22.85 & & 0.23 & & 1.30 & & & & & 0.21 & & 1.24 & 0.66 & 0.31 & 1.25 \\
\hline Verbenone & 13.74 & 45.22 & & & & 31.48 & 1.12 & 3.81 & 0.57 & & 1.32 & & & & \\
\hline Tetradecane & 17.02 & & 0.53 & & & 0.96 & & & 1.73 & & & 3.09 & 1.39 & & 2.44 \\
\hline$\alpha$-Zingiberene & 17.09 & 6.88 & 0.98 & 2.63 & 17.14 & 0.94 & 3.59 & & & & & & & & \\
\hline$Z$ - $\beta$-Farnesene & 17.54 & 0.22 & & & & 0.42 & 0.40 & & 1.49 & & & & 0.41 & 0.49 & \\
\hline Pristane & 21.68 & & & 35.57 & & 9.61 & 58.90 & & 1.56 & & & 1.13 & & 22.57 & \\
\hline $\begin{array}{l}i \text {-propyl } 14 \text {-methyl- } \\
\text { pentadecanoate }\end{array}$ & 26.35 & & & & 3.74 & & 1.44 & 1.44 & 12.26 & & & & 1.54 & 0.57 & \\
\hline Longipinene & 18.40 & 0.72 & & 3.86 & 1.77 & 4.40 & 1.32 & & & & & & & & \\
\hline Ethyl tetradecanoate & 22.58 & 15.96 & & 12.40 & & & & & 2.57 & & & & 1.00 & & 0.92 \\
\hline Dihydrofarnesol & 22.7 & 0.09 & & 0.52 & 1.01 & & 0.82 & & & 22.23 & & & & & \\
\hline Methyl hexadecanoate & 25.08 & & & 0.22 & & & & 1.15 & 0.57 & & 0.78 & & 0.31 & & \\
\hline$\beta$-Myrcene & 8.99 & 0.36 & & & & 0.37 & & 0.23 & & & 3.26 & & & & \\
\hline Tridecane & 15.12 & & & & & & & & 1.25 & & & 2.35 & 1.29 & & 1.63 \\
\hline$E$ - $\beta$-Farnesene & 17.96 & 0.14 & 0.87 & & & & & & & 1.97 & & & & & 7.10 \\
\hline Humulene & 18.08 & 0.11 & & & 0.46 & & & 0.44 & & 0.22 & & & & & \\
\hline $\begin{array}{c}\text { 2,6-Bis(1,1- } \\
\text { dimethylethyl)-2,5- }\end{array}$ & 18.11 & & & 0.19 & & 0.64 & & & & & & & 0.37 & 0.63 & \\
\hline $\begin{array}{c}\text { cyclohexadiene-1,4-dione } \\
\beta \text {-Curcumene }\end{array}$ & 18.13 & & 0.45 & 1.53 & 2.43 & 1.56 & & & & & & & & & \\
\hline$\alpha$-Farnesene & $\begin{array}{l}10.13 \\
18.60\end{array}$ & 0.25 & 0.47 & 1.00 & 2.40 & 1.00 & & 16.97 & & 0.89 & & & & & \\
\hline Nerolidol & 19.73 & & & 0.33 & 1.69 & 0.57 & & & & 0.86 & & & & & \\
\hline Fitone & 23.98 & 0.16 & & 0.28 & 1.32 & & 1.12 & & & & & & & & \\
\hline$\beta$-Pinene & 8.72 & & & & & & & & & 0.18 & 1.13 & & & 0.39 & \\
\hline$p$-Menth-8-en-1-ol & 12.26 & 1.35 & & & & 0.83 & & & & & 21.68 & & & & \\
\hline Decanal & 13.72 & 0.88 & & & & 2.12 & 0.25 & & & & & & & & \\
\hline $\begin{array}{l}\text { 2,6-dimethyl-2,6- } \\
\text { Octadiene }\end{array}$ & 16.72 & & & 0.42 & 1.16 & & 0.32 & & & & & & & & \\
\hline
\end{tabular}


Table 1. Cont.

\begin{tabular}{|c|c|c|c|c|c|c|c|c|c|c|c|c|c|c|c|}
\hline Sample & & Pisticci 1 & Pisticci 2 & Calciano & S. Arcangelo 1 & S. Arcangelo 2 & S. Arcangelo 3 & Tolve 1 & Tolve 2 & Tolve 3 & Pomarico & Vietri 1 & Vietri 2 & Potenza & Savoia \\
\hline Compound & $\begin{array}{c}\text { r.t. } \\
{[\mathrm{min}]}\end{array}$ & \multicolumn{14}{|c|}{ Area $[\%] \pm 0.03$} \\
\hline Pentadecane & 18.49 & 0.12 & 0.45 & 0.79 & & & & & & & & & & & \\
\hline Farnesol & 21.85 & & & & & & 1.70 & & & 36.63 & & & & 19.36 & \\
\hline $\begin{array}{c}\text { Eicosane } \\
\text { cis- } p \text {-menthan-1-ol }\end{array}$ & $\begin{array}{l}25.39 \\
10.93\end{array}$ & 0.46 & & 1.36 & & & & $\begin{array}{l}0.61 \\
0.77\end{array}$ & 0.64 & & & & & & \\
\hline $\begin{array}{l}\text { Linalool } \\
\text { Lister }\end{array}$ & 11.43 & 0.46 & & & & & & & & & & & 0.46 & 0.24 & \\
\hline Citronellal & 13.07 & 0.31 & & & & 0.42 & & & & & & & & & \\
\hline$\alpha$-Terpineol & 13.16 & & & & & & & 0.54 & & & 5.39 & & & & \\
\hline Citronellyl formate & 14.52 & 2.42 & & 0.33 & & & & & & & & & & & \\
\hline Geranyl acetone & 17.52 & & & 0.21 & & 0.37 & & & & & & & & & \\
\hline$\alpha$-Curcumene & 18.28 & & 0.63 & & & & & & & 0.23 & & & & & \\
\hline Tetradecanal & 21.23 & & 0.42 & & 2.24 & & & & & & & & & & \\
\hline Farnesal & 22.04 & & 5.81 & & & & & & & 0.49 & & & & & \\
\hline $\begin{array}{c}2,6- \\
\text { diisopropylnaphthalene }\end{array}$ & 22.22 & & 0.48 & & & & 1.00 & & & & & & & & \\
\hline $\begin{array}{l}\text { 2,3-Dihydrofarnesyl } \\
\text { acetate }\end{array}$ & 22.76 & & & & & & & & & 0.5 & & & & 0.86 & \\
\hline $\begin{array}{c}\text { Pentadecanal } \\
\text { 4-metbyl-3-penten-2-one }\end{array}$ & 23.02 & & 0.21 & & & 0.27 & & & & & & & & & \\
\hline $\begin{array}{c}\text { 4-methyl-3-penten-2-one } \\
\beta \text {-Phellandrene }\end{array}$ & $\begin{array}{l}5.33 \\
9.65\end{array}$ & 0.19 & & & & & & & & & 4.51 & & & & \\
\hline$\gamma$-Terpinene & 10.66 & & & & & & & & & & 5.24 & & & & \\
\hline Geraniol & 14.04 & & & & & & & & & 0.53 & & & & & \\
\hline Citronellyl acid & 15.56 & & & & & & & & & & & & 1.53 & & \\
\hline Citronellyl propionate & 16.1 & 1.02 & & & & & & & & & & & & & \\
\hline Phytan & 22.98 & & & & & & 0.33 & & & & & & & & \\
\hline $\begin{array}{l}\text { Hexahydrofarnesyl } \\
\text { acetone }\end{array}$ & 23.21 & & & & & & & & & & & & & 0.29 & \\
\hline Farnesyl acetate & 23.26 & & & & & & & & & 0.46 & & & & & \\
\hline Isopropyl myristate & 23.35 & & & & & & 0.47 & & & & & & & & \\
\hline Methyl 9-octadecenoate & 26.4 & & & & & & & & & & & & & 0.28 & \\
\hline Heneicosane & 27.05 & & & & & & & & 0.37 & & & & & & \\
\hline Isopropyl linoleate & 27.43 & & & & & & & & & 0.09 & & & & & \\
\hline Number of compounds & & 28 & 20 & 24 & 17 & 21 & 17 & 19 & 20 & 21 & 16 & 14 & 21 & 19 & 14 \\
\hline
\end{tabular}





Figure 5. Multivariate analysis of VOCs emitted by flowers of Barlia robertiana based on the betweensamples Bray-Curtis similarity: (a) non-metric dimensional scaling; (b) UPGMA hierarchical clustering. Labels of samples are accordance with Figure 1. 
Table 2. Comparison of VOCs emitted by two plant samples of Barlia robertiana from the S. Arcangelo site (Basilicata region, S-Italy) detected during the first part of the flowering phase with respect to the last part of the flowering.

\begin{tabular}{|c|c|c|c|c|c|}
\hline \multirow{2}{*}{ Flowering Phase } & & Sample 1 & Sample 2 & Sample 1 & Sample 2 \\
\hline & & \multicolumn{2}{|c|}{ Early } & \multicolumn{2}{|c|}{ Late } \\
\hline Compound & r.t. [min] & & Area \% & & \\
\hline$\alpha$-Pinene & 7.83 & & 0.24 & & 0.61 \\
\hline$\beta$-Myrcene & 9.03 & & 0.29 & & 0.52 \\
\hline D-Limonene & 9.84 & 0.54 & 1.00 & 0.66 & 2.01 \\
\hline Sylvestrene & 11.25 & 0.54 & & & \\
\hline Citronellal & 12.29 & & 1.50 & & 0.61 \\
\hline$\alpha$-Terpineol & 13.17 & & 0.78 & & \\
\hline Verbenone & 13.45 & 0.70 & 0.81 & 0.54 & 0.23 \\
\hline Carvone & 14.07 & & 0.42 & & 0.35 \\
\hline Citronellol & 14.14 & & 42.54 & & 15.66 \\
\hline Methyl (S)-citronellate & 14.24 & 1.28 & 1.06 & 1.23 & \\
\hline 4-Carene & 15.84 & & & & 2.63 \\
\hline$\alpha$-Terpineol acetate & 15.85 & & & & 13.83 \\
\hline $\begin{array}{l}\text { (E,Z)-2,6-Dimethyl-2,6- } \\
\text { octadiene }\end{array}$ & 15.87 & & 0.38 & & \\
\hline Dihydro-b-ionone & 16.20 & 0.42 & & & \\
\hline $\begin{array}{c}\text { 2-Methylene-4,8,8- } \\
\text { trimethyl-4-vinylbicyclo } \\
\text { [5.2.0]nonane }\end{array}$ & 16.70 & 2.52 & & & \\
\hline Caryophyllene & 17.12 & 34.56 & 3.34 & 32.35 & \\
\hline$\alpha$-Bergamotene & 17.29 & 1.10 & 0.50 & & 2.74 \\
\hline$(Z)$ - $\beta$-Farnesene & 17.47 & & 1.50 & 0.57 & 1.99 \\
\hline trans-Geranylacetone & 17.50 & & & & 0.73 \\
\hline$(E)$ - $\beta$-Farnesene & 17.60 & & 5.29 & & \\
\hline 4-Methyltetradecane & 17.65 & & & 30.68 & \\
\hline$\alpha$-longipinene & 17.97 & & & & 0.36 \\
\hline Pentadecane & 18.17 & 4.27 & & 3.78 & \\
\hline$\delta$-Selinene & 18.30 & & & & 0.32 \\
\hline$\beta$-Bisabolene & 18.42 & 4.85 & 3.82 & 6.53 & 6.98 \\
\hline$\beta$-Sesquiphellandrene & 19.35 & & 24.95 & & 44.13 \\
\hline Elemene & 19.54 & 1.14 & & & \\
\hline Hexadecane & 19.65 & 0.98 & & 0.37 & \\
\hline 8-Heptadecene & 20.80 & 1.47 & & 1.60 & \\
\hline 2,3-Dihydrofarnesol & 21.08 & 34.80 & 11.28 & 17.15 & 1.02 \\
\hline $\begin{array}{c}\text { 2,6- } \\
\text { Diisopropylnaphthalene }\end{array}$ & 21.23 & 0.98 & & & \\
\hline Octadecane & 22.41 & 0.98 & & 1.12 & \\
\hline (E)-5-Octadecene & 22.55 & 1.47 & & & \\
\hline Isopropyl miristate & 22.78 & 0.89 & 0.90 & 0.83 & 0.23 \\
\hline Phytone & 22.90 & & & 1.09 & \\
\hline 4-Octadecylmorfoline & 23.60 & 1.40 & & & \\
\hline Nonadecane & 23.70 & & & 0.37 & \\
\hline Methyl hexadecanoate & 24.05 & 0.42 & & & \\
\hline $\begin{array}{l}(E, Z)-5,9,13 \text {-Trimethyl- } \\
4,8,12 \text {-tetradecatrienal }\end{array}$ & 24.32 & 1.61 & & & \\
\hline trans-Geranylgeraniol & 26.50 & 1.61 & & & \\
\hline Number of compounds & & 22 & 18 & 15 & 18 \\
\hline
\end{tabular}

As for inter-annual variations in VOC compositions, unexpectedly, a huge difference was found in the pairwise comparison of the three plants consecutively analyzed in 2018 and 2019 (Table 3). These plants came from the populations of Calciano, Potenza and S. Arcangelo 2; the 2018 samples were also used for spatial variability analyses. The plant from Calciano, as described above, had pristane and ethyl tetradecanoate as main 
components; surprisingly, these two compounds were completely absent from the sample of the following year, substituted by $\alpha$-terpinolene and $(E)-\beta$-farnesene. Additionally, the other two individuals analyzed gave similar results for the main components: in the plant from Potenza, verbenone and D-carvone were not detected in the second year of sampling, which gave pristane and farnesol as the two dominant VOCs. Regarding the plant from S. Arcangelo, verbenone, the main component in 2018, was almost absent in 2019 (0.81\%), whereas $\delta$-selinene, which was the second most abundant, was no more detected. Instead, the main component in 2019 resulted citronellol and $\beta$-sesquiphellandrene. Consequently, the inter-annual between-sample similarity, measured through the Bray-Curtis index, reached only very low values, lower than $9 \%$ (Calciano $4.6 \%$, Arcangelo 5.1\%, Potenza 8.9).

Table 3. Inter-annual variations in VOCs emitted by three individuals of Barlia robertiana sampled in two consecutive years.

\begin{tabular}{|c|c|c|c|c|c|c|c|}
\hline & & Calciano & Calciano & Potenza & Potenza & S. Arcangelo 2 & S. Arcangelo 2 \\
\hline \multicolumn{2}{|c|}{ Year of Sampling } & 2018 & 2019 & 2018 & 2019 & 2018 & 2019 \\
\hline Compound & r.t. [min] & & & & Area $(\%)$ & & \\
\hline$\alpha$-Pinene & 7.83 & 3.02 & 10.63 & 6.43 & 7.87 & 0.46 & 0.24 \\
\hline$\beta$-Pinene & 8.74 & & 0.42 & 0.35 & 0.39 & & \\
\hline Sulcatone & 8.91 & & & 0.19 & & & \\
\hline$\beta$-Myrcene & 9.03 & & 0.65 & 0.33 & & 0.37 & 0.29 \\
\hline$\beta$-Phellandrene & 9.65 & & & 0.06 & & & \\
\hline 2-Ethyl-1-hexanol & 9.83 & & & 0.18 & & & \\
\hline D-limonene & 9.84 & 0.10 & 1.31 & 0.95 & 0.11 & 1.65 & 1.00 \\
\hline Eucaliptol & 9.88 & & 0.35 & 0.35 & & & \\
\hline$\alpha$-Terpinolene & 11.05 & & 32.45 & & & & \\
\hline trans-Sabinene idrate & 11.13 & & & 1.46 & & & \\
\hline $\begin{array}{l}\text { 6-Methyl-2- } \\
\text { pyridinecarboxyaldehyde }\end{array}$ & 11.19 & & & 0.36 & & & \\
\hline Undecane & 11.3 & & & 1.03 & & & \\
\hline Linalool & 11.43 & & & & 0.24 & & \\
\hline Nonanal & 11.45 & & & 1.35 & & & \\
\hline Rose oxide & 11.64 & & & 0.59 & & & \\
\hline 2-Phenylethanol & 11.67 & & & 0.42 & & & \\
\hline p-Menth-8-en-1-ol & 12.26 & & & 1.66 & & 0.83 & \\
\hline Citronellal & 12.29 & & 1,12 & 0.4 & & 0.42 & 1.50 \\
\hline$\alpha$-Terpineol & 13.17 & & 0.45 & 0.17 & & & 0.78 \\
\hline 1-Butoxy-2-ethylhexane & 13.23 & & & 0.18 & & & \\
\hline Verbenone & 13.45 & & 4.72 & 55.18 & & 31.48 & 0.81 \\
\hline Decanal & 13.72 & & & & & 2.12 & \\
\hline Carvone & 14.07 & & & & & & 0.42 \\
\hline Citronellol & 14.14 & & & & 1.53 & 1.34 & 42.54 \\
\hline $\begin{array}{l}\text { cis-Octahydro-3a- } \\
\text { methyl-2H-inden-2-one }\end{array}$ & 14.23 & & 1.80 & & & & \\
\hline Methyl (S)-citronellate & 14.24 & & 1.80 & & & & 1.06 \\
\hline D-carvone & 14.49 & & & 7.92 & & & \\
\hline Citronellyl formate & 14.52 & 0.33 & & & & & \\
\hline (E)-cinnamaldehyde & 14.59 & & 8.25 & & & & \\
\hline Methyl citronellate & 15.03 & 0.30 & & & & & \\
\hline Tridecane & 15.12 & & & 1.55 & & & \\
\hline Citronellyl acid & 15.56 & & & 0.72 & & & \\
\hline Cinnamyl alcohol & 15.80 & & & 0.15 & & & \\
\hline 4-Carene & 15.84 & & 1.53 & & & & \\
\hline $\begin{array}{l}\text { (E,Z)-2,6-Dimethyl-2,6- } \\
\text { octadiene }\end{array}$ & 15.87 & & & & & & 0.38 \\
\hline $\begin{array}{l}\text { 2,6-dimethyl-2,6- } \\
\text { octadiene }\end{array}$ & 16.72 & 0.42 & & & & & \\
\hline
\end{tabular}


Table 3. Cont.

\begin{tabular}{|c|c|c|c|c|c|c|c|}
\hline & & Calciano & Calciano & Potenza & Potenza & S. Arcangelo 2 & S. Arcangelo 2 \\
\hline \multicolumn{2}{|c|}{ Year of Sampling } & 2018 & 2019 & 2018 & 2019 & 2018 & 2019 \\
\hline Compound & r.t. [min] & & & & Area (\%) & & \\
\hline Tetradecane & 17.02 & & & & & 0.96 & \\
\hline$\alpha$-zingiberene & 17.09 & 2.63 & & 0.97 & & 0.94 & \\
\hline Caryophyllene & 17.12 & & 1.74 & 0.32 & 6.75 & & 3.34 \\
\hline$\alpha$-Bergamotene & 17.29 & & 0.64 & & & & 0.50 \\
\hline (Z)- $\beta$-Farnesene & 17.47 & & 1.77 & & 0.49 & 0.42 & 1.50 \\
\hline Trans-Geranyl acetone & 17.50 & & 0.37 & & & & \\
\hline Geranyl acetone & 17.52 & 0.21 & & 0.09 & & 0.37 & \\
\hline cis- $\alpha$-bergamotene & 17.58 & 1.73 & & 0.67 & & 0.77 & \\
\hline $\begin{array}{c}(E) \text { - } \beta \text {-Farnesene } \\
\text { 2,6-bis }(1,1-\end{array}$ & 17.60 & & 14.22 & & & & 5.29 \\
\hline $\begin{array}{l}\text { dimethylethyl)-2,5- } \\
\text { cyclohexadiene-1,4- } \\
\text { dione }\end{array}$ & 18.11 & 0.19 & & & 0.63 & 0.64 & \\
\hline$\beta$-curcumene & 18.13 & 1.53 & & 0.31 & & 1.56 & \\
\hline Longipinene & 18.40 & 3.86 & & 0.34 & & 4.40 & \\
\hline$\beta$-Bisabolene & 18.42 & & 5.22 & & 2.00 & & 3.82 \\
\hline Pentadecane & 18.49 & 0.79 & & & & & \\
\hline$\delta$-selinene & 18.65 & 7.04 & & 1.37 & & 17.59 & \\
\hline$\beta$-sesquiphellandrene & 19.35 & 0.91 & 1.98 & & 8.97 & & 24.95 \\
\hline Hexadecane & 19.65 & & 0.35 & & 1.01 & & \\
\hline Nerolidol & 19.73 & 0.33 & & & & 0.57 & \\
\hline Ethyl dodecanoate & 19.93 & 0.67 & & & 1.10 & 0.33 & \\
\hline 2,3-Dihydrofarnesol & 21.08 & & & & & & 11.28 \\
\hline Heptadecane & 21.29 & 7.41 & & & & & \\
\hline Pristane & 21.68 & 35.57 & & & 22.57 & 9.61 & \\
\hline Farnesol & 21.85 & & & & 19.36 & & \\
\hline Farnesal & 22.04 & & 0.54 & & & & \\
\hline Tetradecanoic acid & 22.5 & 0.30 & & & & & \\
\hline Ethyl tetradecanoate & 22.58 & 12.40 & & 1.23 & & & \\
\hline Dihydrofarnesol & 22.7 & 0.52 & & & & & \\
\hline $\begin{array}{l}\text { 2,3-Dihydrofarnesyl } \\
\text { acetate }\end{array}$ & 22.76 & & & & 0.86 & & \\
\hline Isopropyl miristate & 22.78 & & & & & & 0.90 \\
\hline Octadecane & 22.85 & & & & 0.31 & & \\
\hline pentadecanal & 23.02 & & & & & 0.27 & \\
\hline $\begin{array}{l}\text { Hexahydrofarnesyl } \\
\text { acetone }\end{array}$ & 23.21 & & & & 0.29 & & \\
\hline Fitone & 23.98 & 0.28 & & & & & \\
\hline methyl hexadecanoate & 25.08 & 0.22 & & & & & \\
\hline Eicosane & 25.39 & 1.36 & & & & & \\
\hline $\begin{array}{l}i \text {-propyl 14-methyl- } \\
\text { pentadecanoate }\end{array}$ & 26.35 & & & & 0.57 & & \\
\hline methyl 9-octadecenoate & 26.4 & & & & 0.28 & & \\
\hline Number of compounds & & 24 & 22 & 31 & 19 & 21 & 18 \\
\hline
\end{tabular}

\section{Discussion}

In this study, we identified a very high number of VOCs emitted by Barlia robertiana: considering all the analyzed samples, more than 100 compounds were identified. These results largely encompass the findings of our preliminary study [31].

As for VOC compositions, notably, in a study performed in Spain [32], Gallego et al. found $\alpha$-pinene, $\beta$-pinene, and limonene as the main components of the floral scent of B. robertiana. In our samples, instead, $\alpha$-pinene and limonene were detected, and only at low percentages, and they were not always present (Table 1 ), whereas $\beta$-pinene was found 
with even less frequency and lower percentages. On the other hand, the compounds that most characterize the plants from Italian populations have been not detected in the samples carried out in Spain or, therein, they were only present with very low values; this was the case with verbenone, for example. Considering the influence that analytical tools and sampling procedures may have on the results obtained from VOC analysis, we argue that most of detected differences in the floral scents of $B$. robertiana are due to an intrinsic extreme capability of this species to vary its floral emissions, both qualitatively and quantitatively. At present, the data collected do not allow hypothesizing how much of this variability is under genetic control and how much depends on contingent environmental conditions. What it was possible to ascertain in this study, confirming the preliminary data shown by [31] based on a minor number of samples, is that the variability of floral scents is not related to the geographical distance between populations, nor to the main environmental characteristics of the growth sites. However, even if based on only three samples, the observed variation of the VOCs emitted by the same individual in two consecutive years would seem to indicate a poor genetic determinism for this phenomenon. The mechanisms behind this variability could be related to an intrinsic plasticity of metabolic pathways that lead to the synthesis of VOCs in B. robertiana, but no studies have specifically investigated this aspect thus far.

Several of the detected compounds, such as verbenone and $\alpha$-zingiberene, are known to act as pheromones [33,34]; however, this specific function probably is not specifically used by $B$. robertiana. These results may suggest that there is no adaptation of floral scent to local environments or specific communities of pollinators. In fact, the wide spectrum of VOCs emitted can allow $B$. robertiana to attract different species of insects also belonging to very distant taxonomic groups, as evidenced by some studies on its pollinators [24,25] relying on a large plethora of possible pollinators. The strategy of B. robertiana to attract pollinators manly involves early flowering, showiness and long-lasting inflorescence, traits that can be advantageous for exploiting the first insects that emerged from winter hibernation. Floral scent, a key trait for interaction between plants and insects [35,36], plays an important role for floral mimicry in deceptive species. In this context, a huge variation in flora scent, such as that highlighted by $B$. robertiana, can be considered an effective strategy for a rewardless, but allogamous, species to avoid that visiting insect learn to avoid such flowers. In fact, some studies [37] has been highlighted as rewardlessness can be a dangerous strategy [38]. Despite the causes of rewardlessness are still little known, just a study on B. robertiana showed for the first time the reproductive advantage of the lack of nectar [24]. However, it must be stressed again that this reproductive advantage can only occur if pollinating insects do not learn to associate the floral signals of a species with the lack of nectar inside the flowers.

\section{Conclusions}

We believe that the high variability highlighted in our study about the floral scent emitted within the same population or individual, and the lack of evidence of correlations between flora scents and environmental features (both geographical and ecological) has to be interpreted as an effective strategy carried out by Barlia robertiana to not allow the learning by pollinators, associating floral signals such as scent with a lack of nectar. Similar strategies have been highlighted for other rewardless orchids, such as Ophrys sphegodes Mill. [36]. However, further in-depth studies are needed to investigate several aspects that could not be addressed here. As recently pointed out [35], to investigate specific intra-species variations of floral scent, exploring the less investigated factors that could explain floral scent variations and their mechanisms is a promising research field in light of the evolutionary ecology to which more attention should be given in the future.

Author Contributions: Conceptualization, V.A.R. and L.R.; methodology, L.R., V.A.R. and M.D.; formal analysis, L.R., A.M.R.C., R.R. and M.D.; investigation, V.A.R.; data curation, V.A.R. and M.D.; writing-original draft preparation, L.R., S.F., R.L. and M.D. All authors have read and agreed to the published version of the manuscript. 
Funding: This research received no external funding.

Institutional Review Board Statement: Not applicable.

Informed Consent Statement: Not applicable.

Data Availability Statement: Not applicable.

Conflicts of Interest: The authors declare no conflict of interest.

\section{Appendix A}

Table A1. VOC analysis of Barlia robertiana at different adsorption times.

\begin{tabular}{|c|c|c|c|c|c|}
\hline \multirow{3}{*}{ Compound } & \multirow{3}{*}{ r.t. $[\mathrm{min}]$} & \multirow{3}{*}{ KI } & \multicolumn{3}{|c|}{ Adsorption Time (h) } \\
\hline & & & 5 & 12 & 24 \\
\hline & & & \multicolumn{3}{|c|}{ Area $[\%] \pm \mathbf{0 . 0 3}$} \\
\hline D-limonene & 9.86 & 1022 & 1.35 & 1.04 & 0.93 \\
\hline nonanal & 11.36 & 1103 & & 2.87 & \\
\hline decanal & 13.29 & 1203 & & 3.35 & \\
\hline $4,6,6-$ & & & & & \\
\hline $\begin{array}{l}\text { trimethylbicyclo[3.1.1] ept-3- } \\
\text { en-2-one }\end{array}$ & 13.46 & 1212 & 6.28 & 2.01 & 1.54 \\
\hline methyl (S)-(-)-citronellate & 14.24 & 1258 & 3.44 & 2.64 & 2.68 \\
\hline$\alpha / \beta$-caryophyllene & 17.12 & 1474 & 60.36 & 35.16 & 35.32 \\
\hline 1,3-di-isopropylnaphthalene & 17.13 & 1668 & & 1.71 & \\
\hline trans- $\alpha$-bergamotene & 17.28 & 1433 & & 1.04 & 0.41 \\
\hline $\begin{array}{l}\text { 6,10-dimethyl-5,9- } \\
\text { undecadien-2-one }\end{array}$ & 17.51 & 1453 & 10.92 & & \\
\hline $\begin{array}{l}\text { (E),(Z), } \alpha / \beta-3 \text {-metylene-7,11- } \\
\text { dimethyl-1,6,10-dodecatriene }\end{array}$ & 17.54 & 1459 & & 2.20 & \\
\hline$\beta$-farnesene & 17.60 & 1463 & & 25.60 & 20.71 \\
\hline humulene & 17.66 & 1467 & & 1.08 & \\
\hline pentadecane & 18.17 & 1499 & 3.66 & 5.17 & 3.98 \\
\hline$\beta$-bisabolene & 18.42 & 1515 & 7.03 & 7.56 & 5.60 \\
\hline diethyltoluamide & 19.55 & 1571 & & & 0.97 \\
\hline hexadecane & 19.65 & 1600 & & 1.30 & 4.71 \\
\hline (E),(Z)-8-heptadecene & 20.80 & 1676 & & & 1.42 \\
\hline 2,6-diisopropylnaphthalene & 21.23 & 1695 & & 1.71 & \\
\hline heptadecane & 21.75 & 1700 & & 2.01 & 0.41 \\
\hline 2,3-dihydrofarnesyl acetate & 22.60 & 1805 & & & 2.92 \\
\hline isopropyl myristate & 22.78 & 1827 & 5.16 & 25.83 & 7.15 \\
\hline $\begin{array}{l}\text { (E),(Z)-5,9,13-trimethyl-4,8,12- } \\
\text { tetradecatrienal }\end{array}$ & 23.03 & 1840 & & 1.19 & 1.58 \\
\hline $\begin{array}{l}\text { 7-acetyl-6-ethyl-1,1,4,4- } \\
\text { tetramethyltetraline }\end{array}$ & 23.33 & 1843 & & 0.74 & 0.73 \\
\hline galaxolide & 23.35 & 1850 & & 0.74 & 1.46 \\
\hline 4-octadecyl morfoline & 23.60 & 1880 & 1.80 & & 0.97 \\
\hline methyl hexadecanoate & 24.05 & 1927 & & & 0.77 \\
\hline
\end{tabular}

\section{References}

1. Christenhusz, M.J.M.; Byng, J.W. The number of known plants species in the world and its annual increase. Phytotaxa 2016, 261, 201-207. [CrossRef]

2. Darwin, C. On the Various Contrivances by Which British and Foreign Orchids Are Fertilised by Insects, and on the Good Effects of Intercrossing; Murray, J., Ed.; University of Chicago Press: London, UK, 1862.

3. Vereecken, N.J.; Dafni, A.; Cozzolino, S. Pollination Syndromes in Mediterranean Orchids_-Implications for Speciation, Taxonomy and Conservation. Bot. Rev. 2010, 76, 220-240. [CrossRef]

4. Ackerman, J.D. Mechanisms and evolution of food-deceptive pollination systems in orchids. Lindleyana 1986, 1, 108-113.

5. Jersáková, J.; Johnson, S.D.; Kindlmann, P. Mechanisms and evolution of deceptive pollination in orchids. Biol. Rev. $2006,81,219$. [CrossRef]

6. Johnson, S.D.; Schiestl, F.P. Floral Mimicry, 1st ed.; Oxford University Press: Oxford, NY, USA, 2016. 
7. Kunze, J.; Gumbert, A. The combined effect of color and odor on flower choice behavior of bumble bees in flower mimicry systems. Behav. Ecol. 2001, 12, 447-456. [CrossRef]

8. Galizia, C.G.; Kunze, J.; Gumbert, A.; Borg-Karlson, A.-K.; Sachse, S.; Markl, C.; Menzel, R. Relationship of visual and olfactory signal parameters in a food-deceptive flower mimicry system. Behav. Ecol. 2005, 16, 159-168. [CrossRef]

9. Johnson, S. Batesian mimicry in the non-rewarding orchid Disa pulchra, and its consequences for pollinator behaviour. Biol. J. Linn. Soc. 2000, 71, 119-132. [CrossRef]

10. D'Auria, M.; Lorenz, R.; Mecca, M.; Racioppi, R.; Antonio Romano, V. Aroma components of Cephalanthera orchids. Nat. Prod. Res. 2021, 35, 174-177. [CrossRef]

11. Heinrich, B. Bee flowers: A hypothesis on flower variety and blooming times. Evolution 1975, 29, 325-334. [CrossRef]

12. Johnson, S.D.; Peter, C.I.; Nilsson, L.A.; Ågren, J. Pollination success in a deceptive orchid is enhanced by co-occuring rewarding magnet plants. Ecology 2003, 84, 2919-2927. [CrossRef]

13. Dötterl, S.; Vereecken, N.J. The chemical ecology and evolution of bee-flower interactions: A review and perspectives. Can. J. Zool. 2010, 88, 668-697. [CrossRef]

14. Delforge, P. Orchidées d'Europe, d'Afrique du Nord et du Proche-Orient: La Bible des Orchidophiles, Plus de 600 Espèces et de Nombreuses Variétés et Illustrées; Guide Delachaux; 4e éd.; Revue et augmentée; Delachaux et Niestlé: Paris, France, 2016; ISBN 978-2-603-02407-2.

15. Baumann, H.; Künkele, S.; Lorenz, R. Orchideen Europas: Mit angrenzenden Gebieten; Ulmer-Naturführer; Eugen Ulmer KG: Stuttgart, Germany, 2006; ISBN 978-3-8001-4162-3.

16. Wartmann, B. Orchideen als "Neophyten" in der Schweiz? AGEO Orchis 2020, 1, 9-13.

17. Vögtlin, J. Himantoglossum robertianum (Loisel.) Delforge am Isteiner Klotz. Berichte Bot. Arbeitsgemeinschaft Südwestdtsch. 2008, $5,128$.

18. Bartolucci, F.; Peruzzi, L.; Galasso, G.; Albano, A.; Alessandrini, A.; Ardenghi, N.M.G.; Astuti, G.; Bacchetta, G.; Ballelli, S.; Banfi, E.; et al. An updated checklist of the vascular flora native to Italy. Plant Biosyst. 2018, 152, 179-303. [CrossRef]

19. Sramkó, G.; Molnár, A.V.; Hawkins, J.A.; Bateman, R.M. Molecular phylogenetics and evolution of the Eurasiatic orchid genus Himantoglossum sl. Ann. Bot. 2014, 114, 1609-1626. [CrossRef]

20. Colombo, P.; Giardina, S.; Perrone, A. Studio morfoanatomico di Himantoglossum robertianum ed H. hircinum (Orchidaceae) della Sicilia. J. Eur. Orch. 2009, 41, 359-388.

21. Bazzicalupo, M.; Burlando, B.; Denaro, M.; Barreca, D.; Trombetta, D.; Smeriglio, A.; Cornara, L. Polyphenol Characterization and Skin-Preserving Properties of Hydroalcoholic Flower Extract from Himantoglossum robertianum (Orchidaceae). Plants 2019, 8, 502. [CrossRef] [PubMed]

22. D'Emerico, S.; Galasso, I.; Pignone, D.; Scrugli, A. Localization of rDNA loci by Fluorescent In Situ Hybridization in some wild orchids from Italy (Orchidaceae). Caryologia 2001, 54, 31-36. [CrossRef]

23. Doneddu, M. Osservazioni sull'impollinazione di Barlia robertiana ad opera dei coleotteri Tropinota squalida e Oxythyrea funesta (Cetoniidae) in Sardegna. GIROS Orch. Spont. Eur. 2015, 58, 262-265.

24. Smithson, A.; Gigord, L.D.B. Are there fitness advantages in being a rewardless orchid? Reward supplementation experiments with Barlia robertiana. Proc. R. Soc. Lond. Ser. B Biol. Sci. 2001, 268, 1435-1441. [CrossRef]

25. Sánchez Rosa, E.J. Estudi de la Biologia Reproductiva de L'orquídia Gegant (Barlia robertiana) a L'illa de Mallorca. Ph.D. Thesis, Universitat del les Illes Baleares, Palma, Spain, 2014.

26. Rosati, L.; Romano, V.A.; Cerone, L.; Fascetti, S.; Potenza, G.; Bazzato, E.; Cillo, D.; Mecca, M.; Racioppi, R.; D’Auria, M.; et al. Pollination features and floral volatiles of Gymnospermium scipetarum (Berberidaceae). J. Plant Res. 2019, 132, 49-56. [CrossRef]

27. Rivas-Martınez, S.; Rivas-Saenz, S.; Penas-Merino, A. Worldwide Bioclimatic classification system. Glob. Geobot. $2011,1,1-638$.

28. Canu, S.; Rosati, L.; Fiori, M.; Motroni, A.; Filigheddu, R.; Farris, E. Bioclimate map of Sardinia (Italy). J. Maps 2015, 11, 711-718. [CrossRef]

29. Pesaresi, S.; Galdenzi, D.; Biondi, E.; Casavecchia, S. Bioclimate of Italy: Application of the worldwide bioclimatic classification system. J. Maps 2014, 10, 538-553. [CrossRef]

30. Farris, E.; Filigheddu, R.; Mameli, G.; Falanga, V.; Vanetti, I.; Rosati, L.; Binelli, G. Is population genetic structure of vascular plants shaped more by ecological or geographic factors? A study case on the Mediterranean endemic Centaurea filiformis (Asteraceae). Plant Biol. 2018, 20, 936-947. [CrossRef] [PubMed]

31. D'Auria, M.; Fascetti, S.; Racioppi, R.; Romano, V.A.; Rosati, L. Orchids from Basilicata: The Scent. In Orchids Phytochemistry, Biology and Horticulture; Merillon, J.-M., Kodja, H., Eds.; Springer International Publishing: Cham, Switzerland, 2020; pp. 1-22. ISBN 978-3-030-11257-8.

32. Gallego, E.; Gelabert, A.; Roca, F.J.; Perales, J.F.; Guardino, X. Identification of volatile organic compounds (VOC) emitted from three European orchid species with different pollination strategies: Two deceptive orchids (Himantoglossum robertianum and Ophrys apifera) and a rewarding (Gymnadenia conopsea). J. Biodivers. Environ. Sci. 2012, 2, 18-29.

33. McBrien, H.L.; Millar, J.G.; Rice, R.E.; McElfresh, J.S.; Cullen, E.; Zalom, F.G. Sex Attractant Pheromone of the Red-Shouldered Stink Bug Thyanta pallidovirens: A Pheromone Blend with Multiple Redundant Components. J. Chem. Ecol. 2002, 28, 1797-1818. [CrossRef] [PubMed]

34. Bakthavatsalam, N. Semiochemicals. In Ecofriendly Pest Management for Food Security; Academic Press: Cambridge, MA, USA, 2016; pp. 563-611. 
35. Raguso, R.A. Start making scents: The challenge of integrating chemistry into pollination ecology. Entomol. Exp. Appl. 2008, 128, 196-207. [CrossRef]

36. Schiestl, F.P.; Johnson, S.D. Pollinator-mediated evolution of floral signals. Trends Ecol. Evol. 2013, 28, 307-315. [CrossRef] [PubMed]

37. Smithson, A.; Macnair, M.R. Negative frequency-dependent selection by pollinators on artificial flowera without rewards. Evolution 1997, 51, 715-723. [CrossRef]

38. Moya, S.; Ackerman, J.D. Variation in the floral fragrance of Epidendrum ciliare (Orchidaceae). Nord. J. Bot. 1993, 13, 41-47. [CrossRef] 